this report should be supplemented by the technical reports published in Personal $P_{s y-}$ chology during the 1952-55 period.-Ervin Eatenson, Columbia University Libraries.

\section{Technical Book Review}

Technical Book Review (Science. Engineering. Medicine. Technology), Vol. I, No. I-2, Sept./Oct.-Nov./Dec., 1954. London; E. W. Publications, Ltd. Bi-monthly. I5s.

One of the serious gaps in the book selection apparatus for scientific and technical libraries is a current list of new books. No list of such books now published is adequate for the purpose. With the appearance of the Technical Book Review, it appeared that for the first time such a service might become available.

The principal content of the first two issues was given over to reviews of new books supplemented by a special department headed T.B.R. Register. The following statement precedes the new books listed:

The T.B.R. Register is designed to be a check list giving author, title, number of pages, publisher, price, edition and (where available) brief details of every book recently published or about to be published in the United Kingdom, the British Commonwealth and the U.S. A. With the cooperation of publishers and others, however, we hope that before long the register will be as complete as is practicable. At a later date it is intended to include books in foreign languages.

The first issue listed approximately 235 titles, $64 \%$ of which were British, including only one Empire publication, and $36 \%$ were issued in the United States. With but very few exceptions all of the United States titles listed were shown to also have British outlets. The largest proportion were Wiley and McGraw-Hill publications. An unexpected exception was three titles published by McKnight and McKnight of Bloomington, Illinois. This was obviously inadequate coverage but it was to be understood for a new journal. The editor wrote: "We fully realize the immensity of the task," and expressed hope for full cooperation of publishers in the future.

The second issue, however, recorded many fewer titles and an even smaller percentage of United States publications. (There was also a marked depreciation in the quality of the paper used for the text.) Of the total of 107 titles, $74 \%$ were British, including only one Empire publication, and $26 \%$ were from the United States. The distribution from the U. S. was somewhat better, there being a good representation of two additional publishers, Academic and Reinhold.

The infrequency of publication, coupled with late appearance of the issues, leaves a great deal to be desired for an aid of this kind. The first issue (Sept./Oct.) and the second issue (Nov./Dec.) were received in Chicago respectively on November 22 and February 9.

The first two issues contained 25 and 32 reviews, supplemented in the second issue with a small number of shorter notices. The panel of reviewers promises excellence insofar as the new publications are covered. The merit of reviews, however, in such limited numbers seems questionable. The appearance of reviews in scientific and technical journals such as Science and Nature (among the general publications) and a wide variety of special subject journals seems better to serve the need for reviews. And for an accumulation of critical opinion the Technical Book Review Index has a wider range of practical value to libraries.

On the favorable side the wide subject coverage is to be commended. The criticism of too wide coverage alluded to by the editor in the first issue is, as he suggests, invalid. Isolation among the various sciences is at best wasteful. The arrangement of the T.B.R. Register under the main divisions of the Universal Decimal Classification is very useful. The bibliographic style is good and the typography is adequate, although so compact that on the gray paper of the second issue there is a sharp reduction in readability. -Herman H. Henkle, The John Crerar Library.

\section{Index to Wing}

Index of Printers, Publishers, and Booksellers in Donald Wing's Short-Title Catalogue, I64I-1700. By Paul G. Morrison. Charlottesville: University of Virginia Press, for the Bibliographical Society of 